\title{
InCORPORATING EMPLOYER AND STUDENT ASSESSMENTS INTO A GRADUATE Attribute Assessment Plan
}

\author{
Margaret Gwyn \\ University of Victoria \\ mgwyn@uvic.ca
}

\begin{abstract}
When faced with assessing the Canadian Engineering Accreditation Board (CEAB) graduate attributes, most programs will start by focusing on instructor assessments. Course instructors are uniquely positioned to assess their students' learning, and instructor assessments are sufficient to meet CEAB accreditation requirements. However, for a full picture, data from multiple sources is always desirable. At the University of Victoria, we have chosen to include co-op employer and student assessments in our graduate attribute assessment plan. In this paper, we present the assessment tools we have identified and created, and outline the system we have developed to sustainably produce assessment reports every term for every program. We highlight some of the challenges we have faced, and conclude by discussing our future plans.
\end{abstract}

Keywords: graduate attributes, outcomes assessment, accreditation, CEAB, University of Victoria, employer assessment, co-operative education, student assessment, self-assessment

\section{INTRODUCTION}

As every engineering school in Canada is well aware, the Canadian Engineering Accreditation Board (CEAB) requires that "institutions must demonstrate that the graduates of a program possess the [graduate] attributes" ([6]). Within these requirements, different schools have developed different approaches to graduate attribute assessment. At the University of Victoria, we have decided to include graduate attribute assessment data from co-op employers and from students themselves in our program improvement process. While not explicitly required by $\mathrm{CEAB}$ regulations, we feel this information is very valuable. Co-op is mandatory in our program, so coop employers are also considered instructors of our students. If we don't include their assessments, we can't have a full picture of our students' development. Student self-assessment is also essential: no matter how well others think our students have done, if the students themselves don't feel they have achieved proficiency in the attributes, we have not done our job as educators properly. Co-op employer and student assessments (CESAs) can also be useful to provide data on the highernumbered attributes that are often more difficult to assess in a classroom setting. Finally, the act of surveying co-op employers and students increases their awareness of the graduate attributes and broadens the base of stakeholders involved in program improvement.

Many other schools in Canada also use employer and/or student assessments of the graduate attributes. The University of Manitoba is a notable example: they have a long-running student exit survey program to explore fourth year students' perceptions of the graduate attributes ([1]); they have surveyed students at the beginning and end of technical writing classes to determine their confidence in the communication skills and lifelong learning attributes ([9]); they have held focus groups with a major local employer to obtain an industry perspective on the strengths and weaknesses of their recent graduates ([7]); and most intriguingly, they have asked alumni 18 or more months after graduation to assess their level of competence in the graduate attributes, and compared these results with the level of competence reported by students just before graduation ([12]). The University of Waterloo also has used co-op employer evaluations for graduate attribute assessment ([10]), and student self-assessments of various attributes have been done at the University of Calgary ([11]) and Dalhousie University ([2], [3]).

In this paper, we describe the CESA process that works at UVic: the tools we use to collect data; the system we have developed to manage the data; the challenges we have faced and overcome; and the plans we have to make our process better. The process that works at UVic cannot be applied wholesale at other schools; each school's approach to graduate attribute assessment is and must be unique to that school's situation. However, through the sharing of our individual experiences, we can learn from each other, increase the common pool of ideas and approaches, and work towards the continual improvement of our graduate attribute assessment processes as well as our programs. 


\section{ASSESSMENT TOOLS}

At the University of Victoria we are currently using five different assessment tools to collect graduate attribute assessment data from co-op employers and current engineering students. Some of these tools were purposebuilt for graduate attribute assessment, while others are pre-existing tools that we have re-purposed. Of the preexisting tools, some are unique to UVic, although other institutions may find similar tools available at their own schools. Other of the pre-existing tools are administered by external organizations. The six tools are summarized in Table 1, and discussed in more detail below. Links to a sample of each tool can be found at http://web.uvic.ca/ mgwyn/CEEA2016/.

\subsection{Co-op Employer Assessment Tools}

The Co-op Competency Assessment Tool (CCAT) has been described in detail in a previous publication ([8]). In brief, this tool was developed by UVic's Co-operative Education Program and Career Services Office to allow co-op employers and their students to assess the students' development in several key "competencies". Every UVic co-op employer and their student completes the CCAT online at the beginning, middle and end of each of their work terms. Although not designed specifically with CEAB's graduate attributes in mind, the competencies defined by our Co-op office map well to some of the attributes.

The Last Co-op Employer Survey (LCES) is a purpose-built tool developed by the author. Every term, employers of engineering students who are nearing graduation (i.e., on their fourth or higher work term) are invited by email to go online and rate the extent to which their students demonstrate a set of behaviours related to each attribute (i.e., indicators). This tool has also been previously described in more detail ([8]).

\subsection{Student Self-assessment Tools}

The CCAT, as described in Section 2.1, is done by both co-op employers and their students, and so can also be used as a student self-assessment tool.

The Baccalaureate Graduate Survey (BGS) is conducted by BC Stats on behalf of the BC Student Outcomes Research Forum. The BGS runs every year, surveying alumni of $\mathrm{BC}$ institutions two years after their graduation. Another version of the BGS runs every other year and surveys alumni five years post-graduation; this survey is not currently used for graduate attribute assessment at UVic. Results are made publically available online, and some of the questions of the BGS can be mapped to some of the graduate attributes. While this tool is used only at BC institutions, similar surveys might be available in other provinces.

The National Survey of Student Engagement (NSSE) is conducted by the Center for Postsecondary Research at the Indiana University School of Education. It is conducted every year, asking students at participating institutions in the first and fourth years of their programs about their experiences. At UVic, we participate in the survey every third year. There is a version of the survey specifically designed for Canadian schools and available in both English and French. Again, some of the questions can be mapped to some of the graduate attributes. Results are not made publicly available; at UVic, the Faculty of Engineering can access the data through the university's Office of Institutional Planning and Analysis (OIPA).

Finally, the Exit survey (EXIT) is a purpose-built tool developed by the author. Students are invited to complete the online survey near the time of their convocation. This is usually done by email, although in some years we have also spoken to students at their post-convocation receptions and handed out promotional cards with a link to the survey. Much like the LCES, the EXIT survey goes through each attribute, lists a set of indicators for each, and asks the students to rate the extent to which they demonstrate each behavior. The students are also asked to rate the extent to which their UVic program has contributed to their development in each attribute, and space is provided for comments on each attribute and on the survey overall.

Table 1: CESA tools

\begin{tabular}{|c|c|c|c|c|c|c|c|c|c|c|c|c|c|c|c|}
\hline \multirow{2}{*}{ Tool } & \multirow{2}{*}{ Assessor } & \multirow{2}{*}{$\begin{array}{c}\text { Purpose- } \\
\text { built? }\end{array}$} & \multirow{2}{*}{$\begin{array}{l}\text { Internal } \\
\text { to UVic? }\end{array}$} & \multicolumn{12}{|c|}{ Graduate Attribute Coverage } \\
\hline & & & & 1 & 2 & 3 & 4 & 5 & 6 & 7 & 8 & 9 & 10 & 11 & 12 \\
\hline CCAT & $\begin{array}{c}\text { Employer \& } \\
\text { Student }\end{array}$ & $\mathrm{N}$ & $\mathrm{Y}$ & & $\mathrm{x}$ & $\mathrm{x}$ & & & $\mathrm{x}$ & $\mathrm{x}$ & $\mathrm{x}$ & & $\mathrm{x}$ & $\mathrm{x}$ & $\mathrm{x}$ \\
\hline LCES & Employer & $\mathrm{Y}$ & $\mathrm{Y}$ & $\mathrm{x}$ & $\mathrm{x}$ & $\mathrm{x}$ & $\mathrm{x}$ & $\mathrm{x}$ & $\mathrm{x}$ & $\mathrm{x}$ & $\mathrm{x}$ & $\mathrm{x}$ & $\mathrm{x}$ & $\mathrm{x}$ & $\mathrm{x}$ \\
\hline BGS & Student & $\mathrm{N}$ & $\mathrm{N}$ & $\mathrm{x}$ & $\mathrm{x}$ & & & & $\mathrm{x}$ & $\mathrm{x}$ & & & & & $\mathrm{x}$ \\
\hline NSSE & Student & $\mathrm{N}$ & $\mathrm{N}$ & & & $\mathrm{x}$ & & & $\mathrm{x}$ & $\mathrm{x}$ & & $\mathrm{X}$ & $\mathrm{x}$ & & \\
\hline EXIT & Student & Y & $\mathrm{Y}$ & $\mathrm{x}$ & $\mathrm{x}$ & $\mathrm{x}$ & $\mathrm{x}$ & $\mathrm{x}$ & $\mathrm{x}$ & $\mathrm{x}$ & $\mathrm{x}$ & $\mathrm{X}$ & $\mathrm{x}$ & $\mathrm{x}$ & $\mathrm{x}$ \\
\hline \multicolumn{16}{|c|}{ For a sample of each tool, please visit http://web.uvic.ca/ mgwyn/CEEA2016/ } \\
\hline
\end{tabular}




\section{REPORT GENERATION PROCESS}

Collecting, combining and reporting on the results of CESAs is done at the faculty level for each of our six programs. A timeline of the tasks involved is shown in Table 2 .

Table 2: CESA process timeline

\begin{tabular}{|c|c|}
\hline Month & Task \\
\hline September & - Download summer term LCES results \\
\hline October & $\begin{array}{l}\text { - Receive summer term CCAT results from } \\
\text { Co-op }\end{array}$ \\
\hline November & $\begin{array}{l}\text { - Invite fall convocation students to } \\
\text { complete EXIT } \\
\text { - Receive NSSE results (every third year) }\end{array}$ \\
\hline December & $\begin{array}{l}\text { - Present summer term reports to programs } \\
\text { - Invite fall term co-op employers to } \\
\text { complete the LCES } \\
\text { - Download fall convocation EXIT results }\end{array}$ \\
\hline January & - Download fall term LCES results \\
\hline February & $\begin{array}{l}\text { - Receive fall term CCAT results from } \\
\text { Co-op }\end{array}$ \\
\hline \multicolumn{2}{|l|}{ March } \\
\hline April & $\begin{array}{l}\text { - Present fall term reports to programs } \\
\text { - Invite spring term co-op employers to } \\
\text { complete the LCES }\end{array}$ \\
\hline May & - Download spring term LCES results \\
\hline June & $\begin{array}{l}\text { - Invite summer convocation students to } \\
\text { complete EXIT } \\
\text { - Receive spring term CCAT results from } \\
\text { Co-op }\end{array}$ \\
\hline July & $\begin{array}{l}\text { - Download summer convocation EXIT } \\
\text { results } \\
\text { - Receive BGS results } \\
\end{array}$ \\
\hline August & $\begin{array}{l}\text { - Invite summer term co-op employers to } \\
\text { complete the LCES }\end{array}$ \\
\hline
\end{tabular}

The CCAT, LCES and EXIT are the tools that produce the largest volumes of data. Luckily, this data comes to us from the Co-op office or from our online survey system in Excel format. We have created Excel workbooks for each of these tools to manage their data. After pasting the raw results of the survey into a new tab, links and formulae on the main tab generate results that are ready for inclusion in a report. A sample tool report workbook may be viewed at http://web.uvic.ca/ mgwyn/CEEA2016/.

Once the data is prepared, we use an Excel workbook to generate the report for each program. A master data table tab records all the relevant information for each question used from each assessment tool: the text of the question; the number of assessors who chose each possible response; the number of assessors polled; the category of assessor (employer or student); the tool from which the question came; the attribute to which the question maps; and the date on which the data was last updated.

Finally, each question is numbered in two different ways. The first numbering system puts the rows in order such that data can be easily placed into the table. The second puts the rows in order to properly generate the report, which is done by the remaining tabs of the workbook. Each tab is designed in a format that is ready to print and present to the programs. The report starts with some background on graduate attribute assessment, a summary of the results, and a place for the program to comment on what they see in the results. Next, each assessment tool is described, including the possible responses from which the assessor could choose and the timeframe over which the presented data was collected. Finally, the report goes through each attribute, first giving the results of co-op employer assessment, and then the results of student self-assessment. Data is pulled from the master data table tab and presented both in a table and graphically. A sample program report workbook may be viewed at http://web.uvic.ca/ mgwyn/CEEA2016/.

\section{CHALLENGES}

Including CESAs in a graduate attribute assessment plan can involve challenges. The first of these is collecting the data. For tools that make their results publically or internally available, like the BGS and NSSE, this should theoretically be a simple task. In practice, we found it important to work with our OIPA to gain a deeper understanding of the survey instruments, their questions, and how they are administered. In some cases, the OIPA was also able to provide us with the results of the surveys in alternate formats that made it easier to manage the data.

To collect data from co-op employers, we worked closely with UVic's Co-operative Education Program and Career Services Office. After explaining why we were collecting the data and how we would use it, they agreed to share the raw results of the CCAT with us, and provide us with contact information of co-op employers each term. Without this support, the task of collecting co-op employer assessments would have been much more difficult. For schools that do not have as close and collegial a relationship with their co-op offices, another possible route would be to access co-op employers through the students. Asking students to ask their supervisors to complete an assessment adds a layer of complexity to the process. However, this could be beneficial if it increases the students' understanding of 
and investment in the graduate attribute assessment process.

In parallel with collecting the data, another challenge is managing the data and using it to generate reports. At UVic, we hired various work study students for a total of approximately 440 hours during the early stages of developing the CESA process. In addition to other tasks, these students were very helpful in doing the initial manual data entry and developing the tool and program report generators.

The next major challenge we faced was encouraging the programs to use the collected data. In the years leading up to our first accreditation visit under the new CEAB guidelines, our programs were understandably very focused on developing instructor assessments of the attributes. Although CESA reports had been provided for a number of terms, it was in the term immediately preceding our accreditation visit that the reports were most utilized.

In part, this attitude shift came about as the programs realized that CESAs helped to provide coverage for the attributes that are sometimes more difficult to assess. During the process of our accreditation visit, CESAs were also highlighted as a good way to include qualitative assessments of the attributes, and to expand the pool of stakeholders involved in our assessment process. In retrospect, emphasizing these benefits of CESAs from the beginning could have helped lead to their earlier adoption.

Finally, a last challenge was deciding how to include CESAs in our CEAB questionnaire. The wording of the questionnaire and the design of the required tables are very focused on instructor assessment results. Most of our programs decided to include CESA results under "Compilation and documentation of results" in the Continual Improvement section of Exhibit 1 ([5]).

Another option for programs with mandatory co-op terms is to explicitly include these terms as additional columns in Table 3.1.1. The explanatory text included on this table states: "List all learning activities (courses etc) that relate to specific graduate attributes" (emphasis mine) ([4]). While a co-op work term is not usually considered a course, it should certainly be considered as a learning activity.

\section{CONCLUSIONS AND FUTURE WORK}

CESAs are now an established part of graduate attribute assessment at the University of Victoria. Our staff have found ways to sustainably collect and present the data, our programs have incorporated the results into their analysis, and our accreditation visit has confirmed the value of the process. However, like any process, collecting and reporting on CESAs requires resources that could always be put to use elsewhere. Our future plans, therefore, are focused on increasing the value of CESAs and reducing the resources required.

Our first project is to more fully analyze and better understand the data collected from CESAs. Now that our programs have fully developed their instructor assessment processes, it is possible to compare the assessment results for a given attribute among the three possible assessors. A result from one assessor that is particularly positive or negative as compared to the results from other assessors would be considered a trigger for action when a program's assessment results are analyzed.

The value of CESAs could also be increased by increasing the scope of the data collected. Currently, our CESAs are focused on assessments by students who are close to graduation and their employers. However, the NSSE also offers results from first year students, and the CCAT is completed by students and employers in every co-op work term through the student's degree. The EXIT and LCES tools could also be expanded to gather data from students at other points in their degrees and their employers. Collecting CESAs over an extended time range would allow us to better track how our students are developing over the course of their degrees.

Another addition to our CESAs could be the inclusion of UVic's Course Experience Survey (CES) results. Every student at UVic is invited to complete the CES in each of their classes near the end of every term. The CES is already an accepted and established process at UVic, and as it is managed centrally by the university, it offers a low-effort way to obtain a large amount of student selfassessment data. While most of the questions on the CES are set at the university level and do not map well to the graduate attributes, departments can add up to five customized questions to the survey. If these questions were designed carefully, the CES could be a valuable addition to our CESA suite.

Whether or not we add to our CESA tools, we will continue to work on reducing the time and effort involved in data collection and report generation. A project is currently underway among our programs to unify and streamline their instructor assessment data collection processes. Ideally, the CESA process will also be incorporated into this unified system.

Finally, we must find ways to more seamlessly include CESA results in the data reported to CEAB. This project will start at the Faculty level, but it leads to a bigger question: if graduate attribute assessment beyond coursebased assessment is important to do, how are we to report on it? This question will ultimately need to be answered by the Canadian engineering education community as a whole, and by CEAB itself. 


\section{Acknowledgements}

The author would like to acknowledge Chris Purse from the Office of Institutional Planning and Analysis for his assistance in understanding and using the BGS and NSSE tools, Rhonda Korol and Vanessa Raber from UVic Cooperative Education Program and Career Services for their ongoing support of the CCAT and LCES tools, and Dr. LillAnne Jackson, Associate Dean Undergraduate Programs, under whose guidance the CESA process first begun and continues to evolve.

\section{References}

[1] Jillian S. Cicek, Paul Labossiere, and Sandra Ingram, "Examining Fourth Year Mechanical Engineering Student Perceptions of Graduate Attribute Competencies: Year Three", in Proc. CEEA Canadian Engineering Education Conf., (Hamilton, ON; 31 May - 3 June 2015), 2015.

Available as of May 6, 2016 from http://ojs.library.queensu.ca/index.php/PCEEA/article/view/5 $795 /$ pdf

[2] Anne Marie Coolen, "Implementing a CEAB Engineering Graduate Attributes Based Co-op Work Term Curriculum," in Proc. CEEA Canadian Engineering Education Conf., CEEC11, Andy Fisher (ed.) (St. John's, NL; 6-8 June 2011), 2011. Available as of May 6, 2016 from http://ojs.library.queensu.ca/index.php/PCEEA/article/view/ $3646 / 3659$

[3] Engineering and Computer Science, Dalhousie University, "Graduate Attributes Self-Assessment and Inventory Tool". Available as of May 6, 2016 from http://egad.engineering.queensu.ca/wp-content/documents/ GASelf-Assessmentedited.pdf

[4] Engineers Canada, "Table 3.1.1". Available as of May 9, 2016 from https://www.engineerscanada.ca/sites/default/files/Questionn aire_2014-English-version.zip (under the filename “3.1.1_3.1.2_A6C.xlsm", tab "3.1.1")

[5] Engineers Canada, "Questionnaire for Evaluation of an Engineering Program - Exhibit 1". Available as of May 9, 2016 from https://www.engineerscanada.ca/sites/default/files/Questionn aire_2014-English-version.zip (under the filename "English 2014 Questionnaire - Dec 29 - E1-updated2.doc”)
[6] Engineers Canada Accreditation Board, 2015 Accreditation Criteria and Procedures. Ottawa, ON: Engineers Canada, 2015, 118 pp. \{ISSN 1708-8054\} Available as of May 6, 2016 from https://www.engineerscanada.ca/sites/default/files/accreditat ion_criteria_procedures_2015.pdf

[7] Ken Ferens, "External Assessment of Engineering Programs," in Proc. CEEA Canadian Engineering Education Conf., (Winnipeg, MB; 17-20 June 2012), 2012. Available as of May 6, 2016 from http://library.queensu.ca/ojs/index.php/PCEEA/article/ view/4670/4652

[8] Margaret Gwyn and Rishi Gupta, "Co-op Employer Evaluation of the Graduate Attributes: A Comparison of Two Approaches", in Proc. CEEA Canadian Engineering Education Conf., (Hamilton, ON; 31 May - 3 June 2015), 2015. Available as of May 6, 2016 from http://ojs.library.queensu.ca/index.php/PCEEA/article/view/5 $788 /$ pdf

[9] Anne Parker and Kathryn Marcynuk, "The Self-Reported Confidence and Proficiency Levels of Undergraduate Engineering Students in an Engineering Technical Communication Course", in Proc. CEEA Canadian Engineering Education Conf., (Hamilton, ON; 31 May - 3 June 2015), 2015. Available as of May 6, 2016 from http://ojs.library.queensu.ca/index.php/PCEEA/article/view/5 $805 /$ pdf

[10] Parker, W J, Fondacaro, R and Nespoli, O., "Employing Co-op Employer Evaluations to Assess Outcomes," in Proc. CEEA Canadian Engineering Education Conf., CEEC11, Andy Fisher (ed.) (St. John's, NL; 6-8 June 2011), 2011. Available as of May 16, 2016 from http://ojs.library.queensu.ca/index.php/PCEEA/article/view/ $3611 / 3625$

[11] Robyn Paul and Lynne Cowe Falls, "Engineering Student Leaders' Self-Assessment of Leadership Skills", in Proc. CEEA Canadian Engineering Education Conf., (Hamilton, ON; 31 May - 3 June 2015), 2015. Available as of May 6, 2016 from http://ojs.library.queensu.ca/index.php/PCEEA/article/view/5 $798 /$ pdf

[12] Donald S. Petkau, "Industry Perceptions of Graduate Attribute Competencies", in Proc. CEEA Canadian Engineering Education Conf., (Hamilton, ON; 31 May - 3 June 2015), 2015. Available as of May 6, 2016 from http://ojs.library.queensu.ca/index.php/PCEEA/article/view/5 $785 /$ pdf 